\title{
COMMENTARY
}

\section{On the contributions of David Cleaveland White, MD, PhD to microbial ecology: celebrating the life of a pioneer}

\author{
Brandon EL Morris, Bryan R Crable and Joseph M Suflita
}

The ISME Journal (2008) 2, 797-804; doi:10.1038/ ismej.2008.65; published online 19 June 2008

On 25 October 2006, microbiology lost one of its most prominent and influential figures. Dr David Cleaveland White (DC, to most) succumbed to injuries suffered in an automobile accident. He was eulogized in several obituaries published in Environmental Microbiology and the Journal of Microbiological Methods (Hazen et al., 2006; Phelps and Pfiffner, 2008) that attested to his background, positions held, personality and numerous scientific accomplishments. However, given his impact on the discipline of environmental microbiology, an evocative and more detailed analysis of his scientific contributions seems entirely appropriate. Our goal is to highlight why he was such an important figure. Also, the twelfth annual International Symposium on Microbial Ecology (ISME) brings our thoughts back to DC, as the eleventh ISME conference in Vienna was the last time that many of his colleagues saw him at a professional meeting. In addition, DC's wife Sandy will present the first commemorative David C White award for the most innovative poster presentation at the twelfth ISME conference in August.

DC was a remarkably prolific scholar, publishing over 540 articles, spanning an almost 5-decade career (Figure 1). Roughly one-third of his articles (in approximately equivalent numbers) were published in three journals, Applied and Environmental Microbiology, the Journal of Bacteriology and the Journal of Microbiological Methods. Fittingly, about 5500 of the over 14000 citations to his work are attributable to articles published in these venues. From this large body of work, special notice is given to the more than 20 articles receiving over 100 citations, and his 10 most cited works are listed in Table 1. However, the diversity of his scholarly interests is reflected by the fact that he published in over 150 other journals as well. It is a daunting task to summarize such a diverse and remarkable career, and we have chosen to follow his work more or less chronologically. It is our hope that this approach will reveal some of the underpinning scientific themes that he had so vigorously investigated. Where possible, we have commented on the state-of-the-art at the time of these discoveries and how his contributions impacted the field.

\section{The formative years}

In 1951, DC earned an AB degree in chemistry and geology from Dartmouth College where he was named a Rufus Choate Scholar, a title accorded to students achieving high academic honor. Anyone knowing David would find this distinction to be somewhat prophetic for him to be named after a colorful and eccentric historical figure who earned renown for his often passionate, and yet carefully reasoned, rhetorical arguments. DC went on to medical school at Tufts University (MD, 1955), where he served an internship at the University of Pennsylvania Hospital followed by the US Navy Medical Corps. Subsequent to his medical training, he earned a PhD (1962) from The Rockefeller University where his dissertation research, developed under the tutelage of Sam Granick, focused on hemin biosynthesis. This was an important area of investigation at the time, as the underlying reaction steps tend to be highly conserved in plants, animals and microorganisms. DC demonstrated that hemindependent Haemophilus aegyptius could be transformed to a hemin-independent phenotype by DNA from $H$. parainfluenzae (White and Granick, 1963). This work was also one of the earliest examples of DNA transformation to restore a metabolic lesion in a deficient organism. Basic studies on heme biosynthesis and the general components of microbial respiratory systems represented one of the two major themes DC pursued as he progressed through the academic ranks as a professor at the University of Kentucky Medical Center. In a series of papers, he demonstrated that the model organism so important to his $\mathrm{PhD}$ studies, $H$. parainfluenzae, required an electron transport system containing cytochromes, flavoprotein dehydrogenases, cytochrome oxidases and 2-demethyl vitamin $\mathrm{K}$ for functionality (White, 


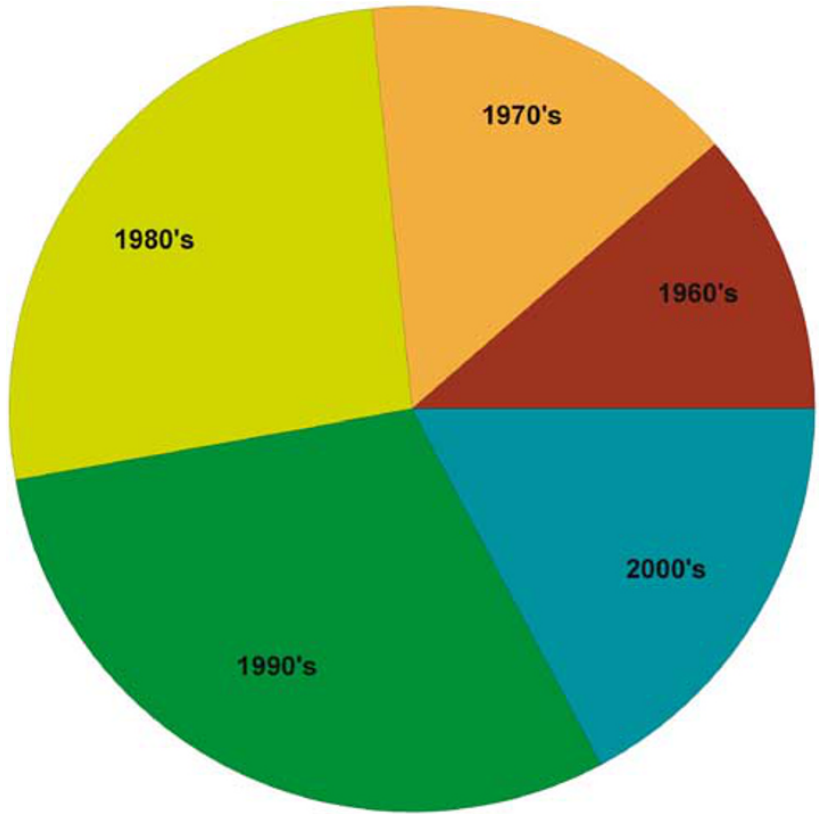

Figure 1 Publications by David C White throughout his career Publication numbers (1960's-61; 1970's-81; 1980's-140; 1990's-160; 2000's-106) are from the Web of Science, accessed on June 2008.

1962, 1968; White and Smith, 1964; Wright and White, 1966). However, the relative amounts of the individual components were correlated with the physiological responses of the bacterium to a variety of stressors and changes in cultivation conditions. He not only showed that the respiratory chain components were formed individually and later inserted into the cytoplasmic membrane (White and Smith, 1962), but also that some molecules could be alternately dissociated from and reassociated into the membrane to influence electron transport activity. Beyond showing that the respiratory chain apparatus was not fixed, such findings helped lay the foundation for his views of how microorganisms generally sensed and responded to alterations in the ambient environmental conditions.

Often in collaboration with others, DC explored cell physiology with other model organisms and systems. For instance, Staphylococcus aureus was a frequent prototypical bacterium, and he demonstrated that the hemin biosynthetic pathway genes were arranged linearly (Sinclair et al., 1967). DC also worked with George C Hill to define the respiratory pigments of the heme-requiring Crithidia fasciculate, a parasitic protozoan of insects, still in use today as a model to study trypanosome diseases of humans (Hill and White, 1968a,b). He collaborated with Caldwell et al. (1962) and investigated the heme requirement in the ruminal organism Bacteroides ruminicola. In that study, DC provided rigorous methods for the quantification of various cell components. Collectively, they found that $B$. ruminicola contained a b-type cytochrome and provided the first experimental evidence for energy generation by an electron transport system in a strictly anaerobic bacterium (White et al., 1962; Caldwell et al., 1965).

The other major theme that captured the research attention of the young Professor White was focused on the lipid matrix wherein the electron transport system was embedded, and his early studies in this area formed the basis for the remainder of his career. Initially, he pursued questions regarding the level of regulation that cells exercised on membrane composition as a function of changes in cultivation conditions. To answer these questions, DC developed technical procedures to extract, isolate and characterize membrane lipids. In fact, the methodological advances associated with the near continual refinement of such procedures characterized his entire career. Intriguingly, he found that several $H$. parainfluenzae membrane lipids were localized and homogeneously distributed (White and Cox, 1967), whereas others were more randomly dispersed. Noting similarities and differences in the lipid composition among Haemophilus strains, he contrasted his findings with Escherichia coli and other organisms. It should be noted that these inquiries were not merely limited to bacteria. For instance, a chemically defined medium was used to explore lipid transformations in the two-spotted spider mite, Tetranychus urticae (Walling et al., 1968). Observations and continued analyses of the patterns of lipid formation revealed organism-specific membrane composition (White, 1968; White and Frerman, 1968; Short et al., 1969; White et al., 1969; White and Tucker, 1969)—a feature at the heart of signature lipid biomarker development. This early phase of DC's career can be characterized by the conduct of rigorous pure culture studies and the examination of detailed biochemical responses of model organisms to various ecological factors. His findings were then extrapolated, and the associated approaches were used to characterize other bacteria, higher trophiclevel organisms and eventually environmental samples. DC was one of the clear leaders in the highly competitive arena of electron transport physiology during his time at the University of Kentucky Medical Center. However, as the 1960s came to an end, DC all but abandoned his work in this realm and focused instead on lipid metabolism-a decision that ultimately served him and science very well.

\section{A change of pace}

Despite the decision to leave the field of membrane energetics, DC's work on cytochromes continued to have an impact on electron transport studies. In 1971, he wrote a review for Advances in Microbial Physiology that focused on branched electron transport systems-a phenomena that his 1960's era work 
Table 1 The ten most highly cited publications of DC White and their significance

\begin{tabular}{|c|c|c|c|c|c|}
\hline & Article title & Authors & Year & $\begin{array}{l}\text { Number of } \\
\text { citations }^{\mathrm{a}}\end{array}$ & Significance \\
\hline (1) & $\begin{array}{l}\text { Determination of the Sedimentary } \\
\text { Microbial Biomass by Extractable } \\
\text { Lipid Phosphate, Oecologia }\end{array}$ & $\begin{array}{l}\text { DC White, JS Nickels, } \\
\text { JD King and RJ Bobbie }\end{array}$ & 1979 & 625 & $\begin{array}{l}\text { This paper demonstrated that } \\
\text { differences in the microbial } \\
\text { community structure could be } \\
\text { discerned using lipids. }\end{array}$ \\
\hline$(2)$ & $\begin{array}{l}\text { Phospholipid, Ester-linked } \\
\text { Fatty-acid Profiles as Reproducible } \\
\text { Assays for Changes in Prokaryotic } \\
\text { Community Structure of Esturarine } \\
\text { Sediments, FEMS Microbiol Ecol. }\end{array}$ & $\begin{array}{l}\text { JB Guckert, CP Antworth } \\
\text { PD Nichols and DC White }\end{array}$ & 1985 & 311 & $\begin{array}{l}\text { In this landmark publication, the } \\
\text { methods and protocols for PLFA } \\
\text { analysis were presented and shown } \\
\text { to be a valid means of measuring } \\
\text { microbial biomass changes across } \\
\text { spatial and temporal scales. }\end{array}$ \\
\hline$(3)$ & $\begin{array}{l}\text { Lipid Analysis in Microbial } \\
\text { Ecology-Quantitative Approaches } \\
\text { to the Study of Microbial } \\
\text { Communities, Bioscience }\end{array}$ & JR Vestal and DC White & 1989 & 261 & $\begin{array}{l}\text { This review article outlines the work } \\
\text { of DC White during the decade of the } \\
\text { 1980s and how the techniques that he } \\
\text { developed could be used to study } \\
\text { communities of microorganisms. }\end{array}$ \\
\hline
\end{tabular}

(4) Geobacter metalloreducens, Gen-nov, Sp-nov, a Microorganism Capable of Coupling the Complete Oxidation of Organic Compounds to the Reduction of Iron and Other Metals, Arch Microbiol.

(5) Determination of Monounsaturated Fatty-acid Double-bond Position and Geometry for Microbial Monocultures and Comples Consortia by Capillary GC-MS of their Dimethyl Disulfide Adducts, J Microbiol Methods

(6) Phospholipid Ester-linked Fattyacid Profile Changes During Nutrient Deprivation of Vibrio cholerae: Increases in the trans/cis Ratio and Proportions of Cyclopropyl Fatty-acids, Appl Environ Microbiol.

(7) Phospholipid Ester-linked Fatty-acid Biomarkers of Acetateoxidizing Sufide-forming Bacteria, J Gen Microbiol.

(8) Reduction of Fe(III) in Sediments by Sulfate-reducing Bacteria, Nature

Hendrick, DR Lovley, of an Experimental Oil Spill, Appl Environ Microbiol.

(10) Equivalence of Microbial Biomass Measures Based on Membrane Lipid and Cell-wall Components, Adenosine-triphosphate, and Direct Counts in Subsurface Aquifer Sediments, Microb Ecol.
DR Lovely, SJ Giovannoni, DC White, JE Champine, EJP Phillips, YA Gorby and S Goodwin

PD Nichols, JB Guckert and DC White

JB Guckert, MA Hood and 1986 DC White

NJE Dowling, F Widdel and DC White

ML Coleman, DB DC White and K Pye

SJ Macnaughton, JR Stephen, AD Venosa, GA Davis, YJ Chang and DC White

This paper characterized the Gramnegative metal-reducer Geobacter metalloreducens. It was also the first discovery of three lipopolysaccharide hydroxy fatty acids (9-, 10- and 11$\mathrm{OH}$ 16:0), in a microbe. They had only previously been found in Eukaryotes and sediments.

This technique article allowed for characterization of lipids up to 26:1 and presented the novel phospholipid ester-linked fatty acid 18:1 $\Delta$ 10c, later used as a signature for methanogenic communities.

This paper suggested that the ratio of cis- to trans-fatty acids may be an indication of nutritional status of microbes within the environment.

Here, the first report of signature fatty acids for acetate-oxidizing and sulfate-reducing bacteria was presented.

This is the first report of sulfatereducing bacteria reducing Fe(III) directly, leading to the formation of siderite. Previously, researchers thought that $\mathrm{Fe}(\mathrm{III})$ was indirectly reduced by the production of hydrogen sulfide.

Three bioremediation techniques were applied to a simulated oil spill, and it was discovered that DGGE may provide additional information when used in conjunction with PLFA.

DL Balkwill, FR Leach, JT Wilson JF McNabb estimation of microbial biomass that
This paper compared the methods for were in use at the time.

${ }^{\mathrm{a} C i t a t i o n ~ n u m b e r s ~ w e r e ~ o b t a i n e d ~ f r o m ~ W e b ~ o f ~ S c i e n c e . ~}$ 
was crucial in establishing (White and Sinclair, 1971). Ultimately, he focused on the development of fundamental techniques for lipid extraction and analysis during the 1970s and began to apply these protocols to questions designed to elucidate the roles that lipids play in the cellular environment.

Only today is science beginning to understand that the cell envelope is a complex array of microdomains, enriched for certain lipids and proteins, anchored or freely floating in a threedimensional matrix. Much of the credit for the earliest work on these topics could go to DC and associates. Early in the 1970s, DC demonstrated the heterogeneous nature of the cell membrane. In collaboration with Anne Tucker, also then at the University of Kentucky Medical Center, it was demonstrated that EDTA-treated $H$. parainfluenzae cells released membrane fragments containing excess cardolipin and phosphatidylglycerol (Tucker and White, 1970a, b). Previously, he had established a possible connection between phosphate metabolism and observed changes in the electron transport structure within the membrane (White and Tucker, 1969). The 1970s papers on cardiolipin led to a series of articles that investigated the combined roles of cardiolipin and phospholipids in the formation of the electron transport chain. Specifically, DC was the first to document phospholipase D activity in a microorganism, previously thought to be a signature feature of plants (Ono and White, 1970a,b). Curious about the metabolism of cardiolipin and related lipids, Tucker and White (1971) speculated that cardiolipin hydrolysis resulted in an increase in phosphatidyl glycerol abundance. Coupled with earlier suggestions that $S$. aureus possessed two distinct classes of cardiolipin (Short and White, 1970, 1971), DC was led to speculate about the heterogeneous nature of cardiolipin metabolism (Tucker and White, 1971). Furthermore, Ono and White (1971) reasoned that cardiolipin may be involved in intracellular transport.

More generally, DC reflected on the metabolism of a wide range of lipids. In Hammond and White (1970a), DC characterized the carotenoids of $S$. aureus, hypothesizing on their involvement in the formation of an electron transport system. In two subsequent articles, it was demonstrated that inhibition of carotenoid synthesis had no effect on electron transport chain composition (Hammond and White, 1970b,c). These papers further developed the idea that the carotenoids were indeed involved in electron transport formation, though to a much lesser extent than previously speculated. Interestingly, data from a study by Joyce and White (1971) suggested that the carotenoids, specifically rubixanthin, may be involved in maintaining growth at suboptimal temperatures, perhaps by performing regulatory functions related to membrane fluidity and/or stability.

\section{The birth of microbial ecology}

The year 1977 marked a turning point for microbial ecology and the career of David C White. During this time, King and White (1977) demonstrated that muramic acid could be used as a quantitative measure of prokaryotic cell mass in sediments and estuarine environments. Before this discovery, researchers understood that prokaryotic biomass represented a large yet uncharacterized fraction of the living biome. However, the lack of suitable tools to accurately measure microbial biomass led to a virtual disregard for microbial assemblages by many investigators. Bacterial counts before this time were done using MPNs, plate counts and ATP determinations, but the muramic acid assay was far more robust than the more traditional methods and did not rely on the nutritional status of the organisms at the time of enumeration (King and White, 1977). The same authors presented a publication 1 month later demonstrating the applicability of signature lipid analysis to monitor growth rates and characterize differences among microbial communities on different types of detritus (King et al., 1977). An inherent need of microbial ecology was met. To understand the dynamics of heterogeneous populations across spatial and temporal scales, the goal of many ecological investigations, researchers must be able to quantify and elucidate differences that are present within the environment and characterize changes in the dynamics of a system. These two papers represent the state-of-the-art for microbial ecology during this period, a marked beginning of what would become the lifework of DC White and so many others. At the close of the 1970s, another contribution would again change microbial ecology-the characterization and quantification of fatty-acid methyl esters. A prophetic aside in White et al. (1979) in Oecologia mentioned that it may be possible to characterize shifts in microbial communities by examining the methyl esters of fatty acids. Remarkably, it is not for this visionary statement, but rather for its outline of methods for bacterial biomass determination by lipid phosphate extraction, to which this paper owes its more than 600 citations (Table 1). More importantly, this procedure reduced the impact that freezing and storage of environmental samples had on determinations of bacterial numbers, a limitation of other techniques in use at the time.

Throughout the early 1980s, the White Lab continued to hone lipid analyses and expanded from determining snapshots of microbial community structure in benthic communities to investigating longitudinal effects of biotic and abiotic parameters such as lighting conditions (Bobbie et al., 1981), silicate grain size and microtopography (Nickels et al., 1981b), and grazing by Gammaridean amphipods (Morrison and White, 1980). As substantive as this work was to DC, he also branched out during this time and began to interrogate the 
microbial dynamics of a process that he called microfouling and the bacterial films associated with fouling communities (Berk et al., 1981). Today, we would describe this process as biocorrosion and are well aware of the impacts that biofilms play in corrosion development. Although the species identifications for members of the fouling community were not available, Nickels et al. (1981a) were able to show that manual brushing actually accelerated the rates of microfouling on both titanium and aluminum surfaces.

Throughout the remainder of his life, DC often spoke about the importance of more holistic approaches to microbial ecology, stressing the need to assess not only the question of community structure, but also that of total viable biomass and nutritional status (White, 1995). Ultimately, the remainder of DC's career would be spent developing and implementing techniques that could be used to answer these very questions in situ. One of the first papers to show nutritional status changes in microorganisms used triglyceride glycerol as a quantitative marker of nutritional status in amphipods (Gehron and White, 1982). Ironically, it was becoming difficult at this time to publish pure methods in some journals, so White founded the Journal of Microbiological Methods in 1982 and served as Editor-in-Chief until 1998. During that formative year, he also founded the Center for Biomedical and Toxicological Research at Florida State University and continued to direct the center until 1985. Also, during this time, researchers were measuring in situ microbial activity like nitrate reduction rates (Henriksen, 1980), and it had already been possible to measure rates of sulfate reduction in sediments for a couple of years (Jorgensen, 1978), but Findlay et al. (1985) illustrated that rates of metabolic activity can vary depending on the methods used to introduce labeled substrates and the amount of disturbance that was imparted on the system of interest.

In 1986, DC left Florida state and started his position at the University of Tennessee and Oak Ridge National Laboratory, where he founded the Institute for Applied Microbiology and acted as Director until 1991. The seminal paper outlining phospholipid fatty-acid analysis was also released during this time (Guckert et al., 1985). It would be an oversight on our part if we did not mention the impact of Peter Nichols during this period in which he and DC coauthored at least 25 papers. DC personally said of Nichols, 'he is the most productive person I have ever worked with' (White, 2007). Impressively, as the number of collaborations grew, DC began to explore the broader spectrum of microbial metabolic capabilities and worked with methanogens as well as other archaea (called archaebacteria then). It was also during this time that DC truly began to explore the principles of in situ remediation and helped to define the modern field of bioremediation. In a 1985 report, he outlined treatment alternatives for hazardous waste and suggested a microbial component for the remediation process (White, 1985). Together with others, DC showed that mineralization of trichloroethylene (TCE) was possible under aerobic conditions (Fliermans et al., 1988), and he began to advocate the manipulation of bacterial community structure within the terrestrial subsurface as a viable bioremediation strategy (White and Wilson, 1989).

Several themes emerge as we begin to explore DC's work during the 1990s. He was involved in multiple studies during the early stages of biocorrosion research, and his contributions in this arena are possibly his most underappreciated. Indeed, this area of investigation is arguably more important today than it was almost 2 decades ago. As he and colleagues pioneered a better understanding of biocorrosion processes and the implications of biofilms on metallic surfaces, DC began to couple his analysis of microbial communities with techniques for non-invasive monitoring of biocorrosion and biofilm functioning. For example, Franklin et al. (1991) demonstrated that bacteria are able to initiate corrosive pitting and that growth of the microbes on carbon steel for extended time periods caused irreversible changes to the metal surface. Those who knew DC will appreciate his irreverent humor on this subject. He once referred to biocorrosion as 'the venereal disease of industry-it is painful, incapacitating, and expensive, but usually unmentioned' (White et al., 1990). DC understood the relevance of procedures allowing for the nondestructive monitoring of biocorrosion processes and advocated the implementation of such technology into industrial and civil circles. In 1991, DC became the Executive Director of the Center for Environmental Biotechnology at the University of Tennessee. Using signature biomarker analysis in conjunction with biocorrosion monitoring techniques, DC was able to finally implicate several species in the microbially influenced corrosion processes. He was also able to compare the rates of aerobic, fermentative and sulfate-reducing processes coupled to corrosion (Jack et al., 1992).

This occupation with microbial transformation of metals by DC, Derek Lovley and other colleagues helped lead to the characterization of Geobacter metallireducens. Aside from demonstrating that the oxidation of a variety of organic compounds could be coupled to the use of $\mathrm{Fe}$ (III) as an electron acceptor (Lovley et al., 1993), this work established that lipopolysaccharide hydroxy fatty acids were also present in microorganisms (Table 1). DC was interested in the rapid identification and characterization of microbial communities, but he also understood the limitations of lipid analyses. With this in mind, during the mid to late 1990s, his work helped usher in the age of nucleotides and gene fusions to quickly determine in situ metabolic activity. In typical fashion, DC was involved at the cutting edge of $16 \mathrm{~S}$ rRNA gene probing and hybridization. Although Amann et al. (1992) were 
one of the first to amplify $16 \mathrm{~S}$ rRNA genes from biofilms, work done at the Center for Environmental Biotechnology together with Gary Sayler successfully created a lux gene fusion from Vibrio fisherii into the naphthalene catabolic region of Pseudomonas fluorescens, allowing naphthalene biodegradation to be monitored by bioluminescence (Heitzer et al., 1994). In addition, the 1990s would not be complete without mentioning the work done toward characterizing the nutritional versatility of Sphinogomonas species. Entire journal volumes have been dedicated to the ecology and physiology of this bacterium, which interestingly contains glycosphingolipids, instead of lipopolysaccarides, in its cell envelope (White et al., 1996).

DC continuously refined his procedures and coupled them with a never-ending zeal to understand the complex interactions of the global microbial biome. He understood that the development of new techniques was necessary to ask increasingly more sophisticated ecological questions. However, as a prescient scholar, DC knew that there was not one 'perfect' technique. He wrote a paper in 1994 entitled 'Is there anything else you need to understand about the microbiota that cannot be derived from analysis of nucleic acids?' (White, 1994). In this work, DC emphasized the need to evaluate phenotypes to garner a more complete understanding of the metabolic potential of microbial communities. One of our favorite articles by DC was published in Oikos in 1995 (White, 1995). Here, DC outlines the importance of microbial ecology and how knowledge of nutrient cycling could complement macroecological investigations. He noted the difficulty in characterizing in situ populations without introducing selective pressures, thereby changing the subject of the scientific scrutiny. Finally, he argued how lipid analyses can be extrapolated from pure cultures to entire microbial communities and how important functions of intact microbial communities can be reliably quantified.

It would require a book perhaps to catalog and comment on all of the research that David Cleaveland White conducted during his almost 5-decade career, the awards he received, his interactions with many collaborators, the groundbreaking nature of his discoveries and his many scientific accomplishments. Here, we have merely tried to highlight several important nodes of his research continuum that have most influenced contemporary microbial ecology and attempted to recognize this distinguished scholar.

\section{Central themes}

In conclusion, we would like to introduce the reader to some of the salient points of DC White's science that are particularly relevant for understanding the continuing significance of his work. From his training as a physician and as a biochemist, DC had a unique perspective on how microbial ecology should be conducted. Although he felt that it was important to characterize shifts in microbial communities, it was more important to assess the status of the important metabolic processes that were driving an ecosystem. Truly, his driving force was to develop techniques to monitor the health of the environment and to find indicators of metabolic function. DC knew that it was imperative to address the 'metabolic potentiality' of an environment (White, 1995). However, realizing that the methods needed to answer these types of questions were not available in the 'microbial ecology handbook,' he bridged the gap between his disciplines and began to explore how inherently quantitative methods of analytical chemistry could be applied to microbial ecology. DC White's thinking was centered on the development of effective tools to triage an environment, to take the pulse of an environment, to discern the salient metabolic features and to determine how contaminant plumes or spatial heterogeneity of nutrient requirements impacted the overall productivity of an ecosystem. He was often quoted as saying that it is not enough to assess the genotype of an environment. Especially during the 1990s, when DNA extraction from soil was hardly efficient, DC understood that the mere presence of a gene does not indicate that the organism is active and functioning in the environment. Before David White, the study of ecological nutrient cycling largely ignored the unseen portion of the biome owing to the difficulty in describing the processes and following the interactions of the habitat in situ. Through the development and identification of signature lipid biomarkers, he provided a quantitative tool to identify many different types of bacteria including Sphingomonas sp. (Leung et al., 1999a,b), Fe(III) reducers (Colwell et al., 1997), fermentative anaerobes (Vrionis et al., 2005), Desulfovibrio species (Duan et al., 1996; Davidson-Arnott et al., 1997) and many more. He also developed procedures to monitor the health of those species in their ecosystem.

In our opinion, DC's greatest contribution to science was his ability to integrate techniques from different disciplines and apply them to the study of microbial ecology. This is where he truly excelled. He provided a road map to elucidate how research efforts, seemingly focused on small problems (identification of lipids), could be applied systematically to the pursuit of larger and broader issues facing microbial ecology and the human population in general (for example, bioremediation and Microbiologically Influenced Corrosion). At first glance, his study of medicine, cytochromes and lipids might seem disjointed and inconsistent. However, when taken together, it becomes clear that the many techniques and iterations pioneered by DC were centered on trying to understand how microbes interact with each other and their surroundings to form the functioning biome that we interact with on a daily basis. 


\section{Acknowledgements}

We would like to graciously thank the following people for helping us collect the articles published by DC White, and for their commentary: Carolina Berdugo, Lauren Bray, Yun-yu Chen, Heather Drilling and Chris Lyles.

BEL Morris is at Department of Botany and Microbiology, The University of Oklahoma, Norman, OK, USA

and Institute for Energy and the Environment, The University of Oklahoma, Norman, OK, USA; $B R$ Crable is at Department of Botany and Microbiology, The University of Oklahoma, Norman, OK, USA and JM Suflita is at Department of Botany and Microbiology, The University of Oklahoma,

Norman, OK, USA and Institute for Energy and the Environment, The University of Oklahoma, Norman, OK, USA E-mail: jsuflita@ou.edu

\section{References}

Amann RI, Stromley J, Devereux R, Key R, Stahl DA. (1992). Molecular and microscopic identification of sulfate-reducing bacteria in multispecies biofilms. Appl Environ Microbiol 58: 614-623.

Berk SG, Mitchell R, Bobbie RJ, Nickels JS, White DC. (1981). Microfouling on metal-surfaces exposed to seawater. Int Biodeterior Bull 17: 29-37.

Bobbie RJ, Nickels JS, Smith GA, Fazio SD, Findlay RH, Davis WM et al. (1981). Effect of light on biomass and community structure of estuarine detrital microbiota. Appl Environ Microbiol 42: 150-158.

Caldwell DR, White DC, Bryant MP. (1962). Specificity of heme requirement for growth of Bacteroides ruminicola-a ruminal saccharolytic bacterium. J Dairy Sci 45: 690.

Caldwell DR, White DC, Bryant MP, Doetsch RN. (1965). Specificity of heme requirement for growth of Bacteroides ruminicola. J Bacteriol 90: 1645-1654.

Colwell FS, Onstott TC, Delwiche ME, Chandler D, Fredrickson JK, Yao QJ et al. (1997). Microorganisms from deep, high temperature sandstones: Constraints on microbial colonization. FEMS Microbiol Rev 20: $425-435$.

Davidson-Arnott RGD, White DC, Ollerhead J. (1997). The effects of artificial pebble concentrations on eolian sand transport on a beach. Can J Earth Sci 34: 1499-1508.

Duan WM, Hedrick DB, Pye K, Coleman ML, White DC. (1996). A preliminary study of the geochemical and microbiological characteristics of modern sedimentary concretions. Limnol Oceanogr 41: 1404-1414.

Findlay RH, Pollard PC, Moriarty DJW, White DC. (1985). Quantitative-determination of microbial activity and community nutritional-status in estuarine sediments-evidence for a disturbance artifact. Can $J$ Microbiol 31: 493-498.

Fliermans CB, Phelps TJ, Ringelberg D, Mikell AT, White DC. (1988). Mineralization of trichloroethylene by heterotrophic enrichment cultures. Appl Environ Microbiol 54: 1709-1714.

Franklin MJ, White DC, Isaacs HS. (1991). Pitting corrosion by bacteria on carbon-steel, determined by the scanning vibrating electrode technique. Corros Sci 32: 945-952.

Gehron MJ, White DC. (1982). Quantitative-determination of the nutritional-status of detrital microbiota and the grazing fauna by triglyceride glycerol analysis. J Exp Mar Biol Ecol 64: 145-158.

Guckert JB, Antworth CP, Nichols PD, White DC. (1985). Phospholipid, ester-linked fatty-acid profiles as reproducible assays for changes in prokaryotic community structure of estuarine sediments. FEMS Microbiol Ecol 31: 147-158.

Hammond RK, White DC. (1970a). Carotenoid formation by Staphylococcus aureus. J Bacteriol 103: 191-198.

Hammond RK, White DC. (1970b). Inhibition of carotenoid hydroxylation in Staphylococcus aureus by mixed-function oxidase inhibitors. J Bacteriol 103: $607-610$

Hammond RK, White DC. (1970c). Inhibition of vitaminK2 and carotenoid synthesis in Staphylococcus aureus by diphenylamine. J Bacteriol 103: 611-615.

Hazen TC, Timmis KN, Stahl DA, DeLong E, Wagner M. (2006). This issue of environmental microbiology is dedicated to the memory of David C. White. Environ Microbiol 8: 2059-2234.

Heitzer A, Malachowsky K, Thonnard JE, Bienkowski PR, White DC, Sayler GS. (1994). Optical biosensor for environmental online monitoring of naphthalene and salicylate bioavailability with an immobilized bioluminescent catabolic reporter bacterium. Appl Environ Microbiol 60: 1487-1494.

Henriksen K. (1980). Measurement of in situ rates of nitrification in sediment. Microb Ecol 6: 329-337.

Hill GC, White DC. (1968a). Characterization of cytochromes in Crithidia fasciculata. J Protozool 15: 22.

Hill GC, White DC. (1968b). Respiratory pigments of Crithidia fasciculata. J Bacteriol 95: 2151-2157.

Jack RF, Ringelberg DB, White DC. (1992). Differential corrosion rates of carbon-steel by combinations of Bacillus sp, Hafnia alvei and Desulfovibrio gigas established by phospholipid analysis of electrode biofilm. Corros Sci 33: 1843-1853.

Jorgensen BB. (1978). Comparison of methods for the quantification of bacterial sulfate reduction in coastal marine-sediments. 1. Measurement with radiotracer techniques. Geomicrobiol J 1: 1978.

Joyce GH, White DC. (1971). Effect of Benzo(a)Pyrene and piperonyl butoxide on formation of respiratory system, phospholipids, and carotenoids of Staphylococcus aureus. J Bacteriol 106: 403-411.

King JD, White DC. (1977). Muramic acid as a measure of microbial biomass in estuarine and marine samples. Appl Environ Microbiol 33: 777-783.

King JD, White DC, Taylor CW. (1977). Use of lipidcomposition and metabolism to examine structure and activity of estuarine detrital microflora. Appl Environ Microbiol 33: 1177-1183.

Leung KT, Campbell S, Gan YD, White DC, Lee H, Trevors JT. (1999a). The role of the Sphingomonas species UG30 pentachlorophenol-4-monooxygenase in p-nitrophenol degradation. FEMS Microbiol Lett 173: 247-253.

Leung KT, Chang YJ, Gan YD, Peacock A, Macnaughton SJ, Stephen JR et al. (1999b). Detection of Sphingomonas 
spp in soil by PCR and sphingolipid biomarker analysis. J Ind Microbiol Biotechnol 23: 252-260.

Lovley DR, Giovannoni SJ, White DC, Champine JE, Phillips EJP, Gorby YA et al. (1993). Geobacter metallireducens Gen-Nov Sp-Nov, a microorganism capable of coupling the complete oxidation of organiccompounds to the reduction of iron and other metals. Arch Microbiol 159: 336-344.

Morrison SJ, White DC. (1980). Effects of grazing by estuarine gammaridean amphipods on the microbiota of allochthonous detritus. Appl Environ Microbiol 40: 659-671.

Nickels JS, Bobbie RJ, Lott DF, Martz RF, Benson PH, White DC. (1981a). Effect of manual brush cleaning on biomass and community structure of micro-fouling film formed on aluminum and titanium surfaces exposed to rapidly flowing seawater. Appl Environ Microbiol 41: 1442-1453.

Nickels JS, Bobbie RJ, Martz RF, Smith GA, White DC, Richards NL. (1981b). Effect of silicate grain shape, structure, and location on the biomass and community structure of colonizing marine microbiota. Appl Environ Microbiol 41: 1262-1268.

Ono Y, White DC. (1970a). Cardiolipin-specific phospholipase-D activity in Haemophilus parainfluenzae. J Bacteriol 103: 111-115.

Ono Y, White DC. (1970b). Cardiolipin-specific phospholipase-D of Haemophilus parainfluenzae 2. Characteristics and possible significance. $J$ Bacteriol 104: 712-718.

Ono Y, White DC. (1971). Consequences of inhibition of cardiolipin metabolism in Haemophilus parainfluenzae. J Bacteriol 108: 1065-1071.

Phelps TJ, Pfiffner SM. (2008). Tribute to the scientific accomplishments of David Cleaveland White. J Microbiol Methods 74: 1-4.

Short SA, White DC. (1970). Metabolism of glucosyl diglycerides and phosphatidylglucose of Staphylococcus aureus. I Bacteriol 104: 126-132.

Short SA, White DC. (1971). Metabolism of phosphatidylglycerol, lysylphosphatidylglycerol, and cardiolipin of Staphylococcus aureus. J Bacteriol 108: 219-226.

Short SA, White DC, Aleem MIH. (1969). Phospholipid metabolism in Ferrobacillus ferrooxidans. J Bacteriol 99: $142-150$.

Sinclair P, White DC, Barrett J. (1967). Conversion of protoheme to heme a in Staphylococcus. Biochimica Et Biophysica Acta 143: 427.

Tucker AN, White DC. (1970a). Metabolism of phospholipid 2-linked fatty acids during release of membrane fragments from Haemophilus parainfluenzae by ethylenediaminetetraacetic acid-Tris(Hydroxymethyl)Aminomethane. J Bacteriol 103: 329-334.

Tucker AN, White DC. (1970b). Release of membrane components from viable Haemophilus parainfluenzae by ethylenediam-inetetraacetic acid-Tris(hydroxymethyl)-aminomethane. J Bacteriol 102: 498-507.

Tucker AN, White DC. (1971). Detection of a rapidly metabolizing portion of membrane cardiolipin in Haemophilus parainfluenzae. J Bacteriol 108: 1058-1064.

Vrionis HA, Anderson RT, Ortiz-Bernad I, O'Neill KR, Resch CT, Peacock AD et al. (2005). Microbiological and geochemical heterogeneity in an in situ uranium bioremediation field site. Appl Environ Microbiol 71: 6308-6318.

Walling MV, White DC, Rodrigue JG. (1968). Characterization distribution catabolism and synthesis of fatty acids of 2-spotted spider mite Tetranychus urticae. J Insect Physiol 14: 1445.

White DC. (1962). Cytochrome and catalase patterns during growth of Haemophilus parainfluenzae. J Bacteriol 83: 851-859.

White DC. (1968). Lipid composition of electron transport membrane of Haemophilus parainfluenzae. J Bacteriol 96: $1159-1170$.

White DC. (1985). EPA program for treatment alternatives for hazardous-waste. J Air Pollut Control Assoc 35: 369-372.

White DC. (1994). Is there anything else you need to understand about the microbiota that cannot be derived from analysis of nucleic-acids. Microb Ecol 28: 163-166.

White DC. (1995). Chemical ecology: possible linkage between macro- and microbial ecology. Oikos 74: 177-184.

White DC. (2007). Vol. 2008. Siren Interactive. (url:http:// www.davidcwhite.org).

White DC, Caldwell DR, Bryant MP. (1962). Cytochromelinked fermentation on Bacteroides ruminicola. J Bacteriol 84: 822-828.

White DC, Cox RH. (1967). Identification and localization of fatty acids in Haemophilus parainfluenzae. J Bacteriol 93: 1079-1088.

White DC, Davis WM, Nickels JS, King JD, Bobbie RJ. (1979). Determination of the sedimentary microbial biomass by extractable lipid phosphate. Oecologia 40: 51-62.

White DC, Frerman FE. (1968). Fatty acid composition of complex lipids of Staphylococcus aureus during formation of membrane-bound electron transport system. J Bacteriol 95: 2198-2209.

White DC, Granick S. (1963). Hemin biosynthesis in Haemophilus. J Bacteriol 85: 842-850.

White DC, Jack RF, Dowling NJE. (1990). The microbiology of MIC. In: Dowling NJE, Mittelman MW, Danko JC (eds). Microbially Influenced Corrosion and Biodeterioration. International Congress on Microbially Influenced Corrosion: Knoxville, TN. pp 11-19.

White DC, Sinclair PR. (1971). Branched electron-transport systems in bacteria. Adv Microb Physiol 5: 173-211.

White DC, Smith L. (1962). Hematin enzymes of Hemophilus parainfluenzae. J Biol Chem 237: 1332-1336.

White DC, Smith L. (1964). Localization of enzymes that catalyze hydrogen+electron transport in Hemophilus parainfluenzae+nature of respiratory chain system. J Biol Chem 239: 3956-3963.

White DC, Sutton SD, Ringelberg DB. (1996). The genus Sphingomonas: physiology and ecology. Curr Opin Biotechnol 7: 301-306.

White DC, Tucker AN. (1969). Phospholipid metabolism during changes in proportions of membrane-bound respiratory pigments in Haemophilus parainfluenzae. J Bacteriol 97: 199-209.

White DC, Tucker AN, Sweeley CC. (1969). Characterization of Iso-branched sphinganines from ceramide phospholipids of Bacteroides melaninogenicus. Biochimica Et Biophysica Acta 187: 527.

White DC, Wilson JW. (1989). Subsurface microbiota as monitors of contaminant migration and mitigation. In: Molz FJ (ed). Symposium on New Field Techniques for Quantifying the Physical and Chemical Properties of Heterogeneous Aquifers. National Water Well Association: Dublin, $\mathrm{OH}$.

Wright EA, White DC. (1966). Formation of a functional electron transport system during growth of penicillininduced spheroplasts of Haemophilus parainfluenzae. J Bacteriol 91: 1356-1362. 